\title{
DEVELOPMENT OF CLASSROOM MICROCLIMATE MONITORING SYSTEM
}

\author{
Armands Kviesis, Amanda Klavina, Gatis Vitols \\ Latvia University of Agriculture \\ armands.kviesis@1lu.lv, amanda.klavina@inbox.lv, gatis.vitols@1lu.lv
}

\begin{abstract}
Microclimate in classrooms can affect students' productivity. Since nowadays students and existing specialists of various fields, including engineering, most of the day spend indoors, it is important to ensure quality environment that would increase their productivity. It is important to pay attention to room microclimate factors that include temperature, air humidity and quality. Microclimate requirements are also regulated in the country legislation and organizations have to follow certain requirements. Therefore, it is important to perform detailed monitoring of microclimate. As technologies evolve there are various sensors offered in market that perceive certain microclimate parameters. These parameters inadequacy to recommended indicators can cause all kinds of health and work quality affecting problems as headaches, sleepiness, tiredness that results with lower concentration powers. In this research technological solutions for microclimate monitoring were introduced as a system prototype that measures microclimate parameters in classrooms. The monitoring system is based on the Arduino platform with sensors for measuring air temperature, humidity and carbon dioxide level. Additionally, a desktop application was developed to represent data remotely and receive warnings about microclimate indicator deviation from the recommended values. The developed system is used to monitor microclimate in the computer room at the Faculty of Information Technologies, Latvia University of Agriculture. During the research it was concluded that in non-ventilated room the $\mathrm{CO}_{2}$ level was always above the recommended value (1000 ppm) about $1500 \mathrm{ppm}$, temperature was slightly over the maximum recommended value $\left(25^{\circ} \mathrm{C}\right)$ but relative humidity was slightly over the minimum recommended value $(30 \%)$. The developed prototype can be scalable and adjusted for application in multiple buildings and organizations.
\end{abstract}

Keywords: air quality, Arduino, carbon dioxide, humidity, temperature.

\section{Introduction}

Room microclimate effect on human health and work productivity has been studied in several researches [1-3]. Poor microclimate can cause health problems, like irritation of eyes, nose and throat, tiredness, headaches, rhinitis and nasal congestion etc. [4]. There are a lot of factors that affect the room air quality - room microclimate, outdoor air pollution, indoor pollution, biological pollution and human [5]. Various sources consider the air temperature, humidity and $\mathrm{CO}_{2}$ level to be the main microclimate parameters $[4 ; 6 ; 7]$. Each climate zone and country have their own regulations and standards about indoor microclimate and its parameter values [7]. Latvia's legislation states that the first floor indoor temperature has to be: 19 to $25^{\circ} \mathrm{C}$ during the cold period of the year and 20 to $28^{\circ} \mathrm{C}$ during the warm period of the year. The indoor air humidity has to be 30-70\% [8]. Several articles and sources [9-12] state that the recommended maximum level of $\mathrm{CO}_{2}$ concentration is $1000 \mathrm{ppm}$. By [10], air that has the $\mathrm{CO}_{2}$ concentration level in range of 350-1000 ppm is good and does not cause health problems; $1000-2000 \mathrm{ppm}$ is considered poor and causes drowsiness; 2000-5000 ppm is considered as stale, stuffy air and causes headaches, sleepiness and loss of attention, and increases the heart rate.

There are various studies devoted to microclimate monitoring. In [13] research the authors used TSI DustTruck instrument to measure the classroom air quality parameters. In Poland similar research was conducted - microclimate parameters in University computer laboratories were measured and it was discovered that in these computer laboratories the indoor air quality was poor due to improper management of air exchange [9]. In Liepaja [14] there was research conducted during the heating season. Measurements were carried out with LumaSense Technologies INNOVA 1303. It was concluded that air exchange was low and the fresh air supply was insufficient.

Nowadays, development of small size computers and electronic platforms has become very popular and economically available. One of such is an inexpensive open-source electronic development platform - Arduino [15]. Such electronic boards can be used as an alternative to more expensive measuring instruments, therefore it is a great solution for smaller organizations. Although it should be noted that different measurement accuracy will be highly dependent on the programmed software and the sensors used. 
The aim of this paper is to improve microclimate monitoring in computer laboratories using opensource hardware and software solutions.

\section{Materials and methods}

A measurement system was developed using components, such as: Arduino Uno platform, K-30 sensor module, SHT75 humidity and temperature sensor, ESP8266 Wi-Fi module.

The datasheet [16] Sensirion SHT75 has a typical measurement accuracy of $\pm 0.3{ }^{\circ} \mathrm{C}$ (typical resolution $-0.01{ }^{\circ} \mathrm{C}$ ) for temperature readings and $\pm 1.8 \%$ (typical resolution $-0.05 \%$ ) for relative humidity readings. The sensor can be powered with source voltage between 2.4 and $5.5 \mathrm{~V}$. During the measurement stage the sensor has a power consumption of $3 \mathrm{~mW}$.

$\mathrm{CO}_{2}$ sensor module $\mathrm{K}-30$ by datasheet [17] has a measurement accuracy of $\pm 30 \mathrm{ppm}+3 \%$ of measured value within specification; sensitivity: $\pm 20 \mathrm{ppm}$. The sensor measurement range is between 0 and $5000 \mathrm{ppm}$ within specifications and 0 to $10000 \mathrm{ppm}$ total $\mathrm{CO}_{2}$ detection range. It requires 5$14 \mathrm{~V}$ of power input, however a different source [18] suggests to use 6-9V. Typically K-30 consumes $40 \mathrm{~mA}$, the peak current during IR lamp ON and during IR lamp start-up does not exceed $150 \mathrm{~mA}$ and $300 \mathrm{~mA}$, respectively.

The K-30 sensor module was compared with the testo 535 instrument. The testo 535 measuring range is between 0 and $9999 \mathrm{ppm}$, accuracy: $\pm 50 \mathrm{ppm}+2 \%$ of measured value (range 0 to $5000 \mathrm{ppm}$ ) and $\pm 100 \mathrm{ppm}+3 \%$ of measured value at 5000 to $9999 \mathrm{ppm}$. For comparison purposes, both the K-30 sensor module and testo 535 measured the $\mathrm{CO}_{2}$ level at the same time in fresh air (close to opened window) for 10 minutes. As it was said, in the testo 535 manual [19], readings in fresh air should be from 350 to $450 \mathrm{ppm}$. In the fresh air the measured mean values differed by $58 \mathrm{ppm}$ (K-30: $479 \mathrm{ppm}$; testo 535: $421 \mathrm{ppm})$.

Wi-Fi module used in this research (ESP8266) has a low powered 32-bit MCU that operates with $3.0-3.6 \mathrm{~V}$ with average operating current of $80 \mathrm{~mA}$ [20]. Communication was performed using only TX and RX pins to send AT instructions.

Sensor readings were registered each 5 minutes. Data were sent to a remote MySQL database, were data can then be accessed using a developed local, mobile or WEB application. Data transfer was performed using Hypertext Transfer Protocol (HTTP) and GET method. Arduino was connected to the wireless Internet using a Wi-Fi module ESP8266. Connection and GET request were performed using AT commands. Below is an example of the GET request: GET / script.php? $t=24 \& h=30 \& \mathrm{co} 2=900$

The described monitoring system was setup in one computer laboratory (further Room_1) located on the first floor, where students were having their practical assignments. Room_1 specifics: area $54.6 \mathrm{~m}^{2}$; height $-3 \mathrm{~m}$; desktop computer count -16 . Measurement node was placed on a table at the height $0.74 \mathrm{~m}$ opposite the windows as suggested in [21]. Room_1 was monitored for 7 days.

The system was based on architecture shown in Fig. 1.

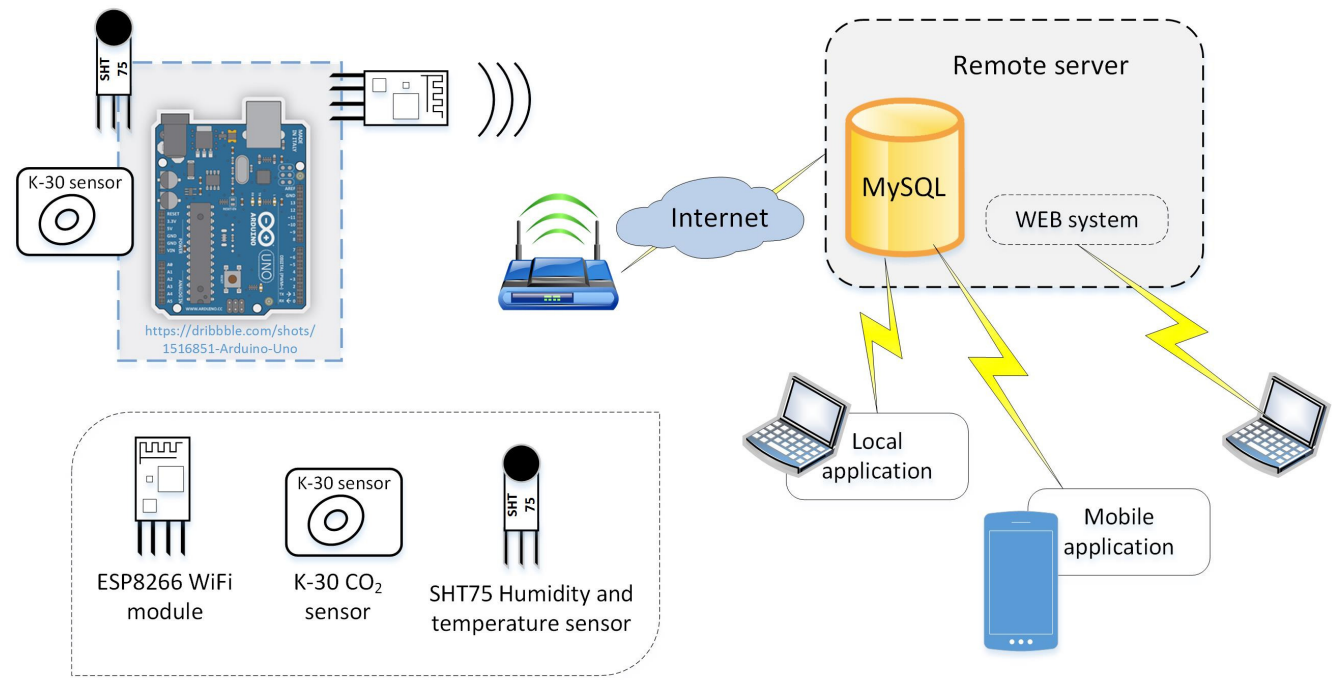

Fig. 1. Microclimate monitoring system architecture 


\section{Results and discussion}

\section{Measured microclimate parameters}

As stated by [22], sensor measurement interpretation, particularly $\mathrm{CO}_{2}$ sensor measurements, may lead to error that is more significant, than the instrument accuracy. It is stated that to get meaningful assumptions, the monitoring object, in this case, Room_1, should be occupied by people long enough, so the $\mathrm{CO}_{2}$ level could reach the steady state [22]. In our research, steady state was not possible to reach, as students are only occupying the room for 45 minutes (length of one lecture/practical assignment), after then they usually leave the room. This time is not enough for the $\mathrm{CO}_{2}$ level to reach the steady state. When the next group of students enters the room, the student count might not be the same as the previous group that results in $\mathrm{CO}_{2}$ level fluctuations. These fluctuations are illustrated in Fig. 2.

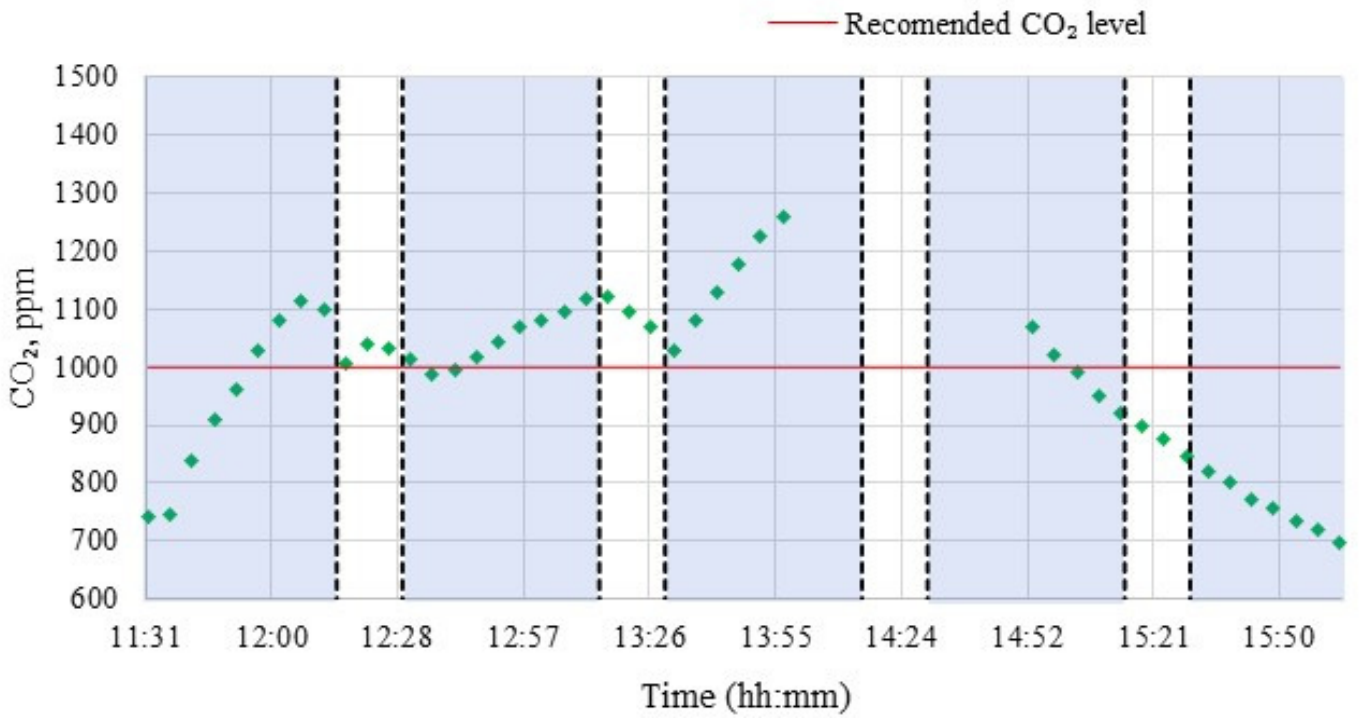

Fig. 2. Example of $\mathrm{CO}_{2}$ level fluctuations in Room_1

The shaded areas in Fig. 2 represent the time during practical assignments (45 minutes), white area - break time (15 minutes) in Room_1. As it can be seen, during the breaks the $\mathrm{CO}_{2}$ level decreases, but its value is always close or above $1000 \mathrm{ppm}$ (the recommended maximum value). It was found that from 11:30 till 12:15 there were 14 people (students and the lecturer). The diagram shows that this is the first practical assignment, since the $\mathrm{CO}_{2}$ level dramatically increases (from $744 \mathrm{ppm}$ to 1115 ppm). From 12:30 to 13:15 7 people were occupying Room_1, but from 13:30 to 14:15 there were 12 people in Room_1. During the time from 13:55 to 14:54 there was a technical issue with the monitoring system, thus no data were registered.

It was concluded, that in empty Room_1 (empty room data gathered only for two days - day 1 and day 4) before students arrived, the average $\mathrm{CO}_{2}$ level on day 1 was $457.29 \mathrm{ppm}$ with standard deviation $\pm 6.88 \mathrm{ppm}$ and $445.5 \mathrm{ppm} \pm 3.43 \mathrm{ppm}$ on day 4 , and started to increase when the students (total people count during practical assignment -11) started to enter the room.

The temperature level in Room_1 was slightly over the recommended maximum value $\left(25^{\circ} \mathrm{C}\right)$. When Room_1 was empty (data gathered on day 1 and day 4), average temperature on day 1 was $+21.01{ }^{\circ} \mathrm{C}$ with standard deviation $\pm 0.14{ }^{\circ} \mathrm{C}$ and $+22.64{ }^{\circ} \mathrm{C} \pm 0.2{ }^{\circ} \mathrm{C}$ on day 4 . Based on the Internet resource [23] hourly observation data, the outside maximum temperature from 9:00 to 11:00 in these days were in range from -1.6 to $-1.3{ }^{\circ} \mathrm{C}$ and from -1.9 to $+2.2{ }^{\circ} \mathrm{C}$ respectively. When the students started to enter the room, the temperature slowly increased, reaching the maximum recommended value and exceeded it slightly. The outside temperature at that time was in range from -1.3 to $-0.4{ }^{\circ} \mathrm{C}$ on day 1 and from +2.2 to $5.1^{\circ} \mathrm{C}$ on day 4 . It was observed that the temperature value in Room_1 was between the recommended values when the outside temperature minimum was from -1.7 to $-0.6^{\circ} \mathrm{C}$.

It was concluded that relative humidity was below the recommended values most of the time. It was observed that when the outside relative humidity was over $90 \%$ the relative humidity inside the 
Room_1 was still below the recommended minimum. Relative humidity was over the recommended minimum value when the outside temperature minimum was above $0{ }^{\circ} \mathrm{C}$. When Room_1 was empty, the relative humidity value was still below the recommended minimum value (average: $25.93 \%$ with standard deviation $\pm 0.24 \%$ on day 1 and $24.55 \% \pm 0.38 \%$ on day 4 ).

\section{Periodical window opening during study breaks}

During student practical assignment, a window was opened for a short time (10 - 12 minutes) in Room_1 at about 9:45 (Fig. 3) in order to decrease the $\mathrm{CO}_{2}$ level (approximately $1113 \mathrm{ppm}$ ). 9 people were in Room_1 at that time. As it is shown in Fig. 3, when window was opened the $\mathrm{CO}_{2}$ level decreased rapidly (from 1113 to $779 \mathrm{ppm}$ ), relative humidity and temperature also changed. Measured parameter fluctuations periodically recur due to opened window (after each practical assignment). It was also noticed that at 10:30 there was one sudden spike in all measured parameters that can be interpreted as a measurement error.

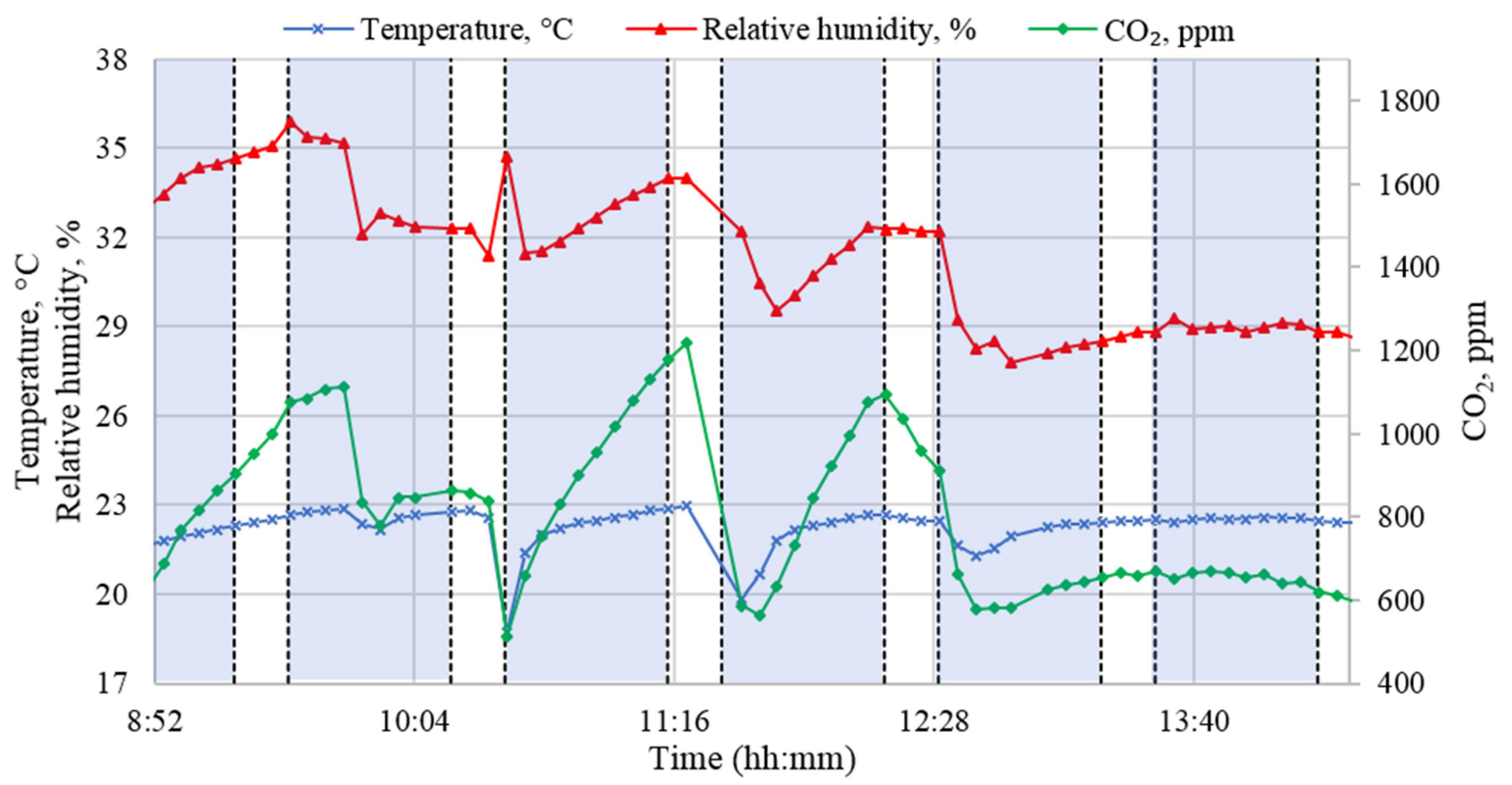

Fig. 3. Microclimate parameter fluctuations when window was periodically opened

During the monitoring process, the window was opened while the students were having practical assignment. There were total of 11 people in Room_1 during this period. The monitored parameters did not have significant fluctuations: average $\mathrm{CO}_{2}$ level was $590 \mathrm{ppm}$ with standard deviation $\pm 22.43 \mathrm{ppm}$; average temperature $+21.71{ }^{\circ} \mathrm{C} \pm 0.28{ }^{\circ} \mathrm{C}$; average relative humidity $24.65 \% \pm 0.53 \%$. Relative humidity was the only parameter that did not satisfy the recommended values (recommended minimum: $30 \%$ ). The measured parameter mean values are presented in Table 1 .

Table 1

Mean values of measured parameters in different conditions

\begin{tabular}{|l|c|c|c|}
\hline \multicolumn{1}{|c|}{ Condition } & $\boldsymbol{T},{ }^{\mathbf{0}} \mathbf{C}$ & $\boldsymbol{R H}, \boldsymbol{\%}$ & $\mathbf{C O}_{2}, \mathbf{p p m}$ \\
\hline $\begin{array}{l}\text { Empty Room_1 (before the first practical } \\
\text { assignment) }\end{array}$ & $21.01 \pm 0.14$ & $25.93 \pm 0.24$ & $457.29 \pm 6.88$ \\
\hline 14 people in Room_1 (for 45 min) & $25.50 \pm 0.18$ & $30.24 \pm 0.35$ & $1518.56 \pm 52.40$ \\
\hline $\begin{array}{l}\text { After opened window 14 persons in } \\
\text { Room_1 (for 45 min) }\end{array}$ & $21.90 \pm 0.99$ & $31.18 \pm 1.03$ & $827.33 \pm 207.58$ \\
\hline $\begin{array}{l}\text { 14 people in Room_1 (approx. 2 hour } \\
\text { period, including breaks) }\end{array}$ & $25.21 \pm 0.42$ & $29.93 \pm 0.61$ & $1384.53 \pm 183.00$ \\
\hline $\begin{array}{l}\text { 14 people in well ventilated Room_1 } \\
\text { (approx. 2 hour period, including breaks) }\end{array}$ & $22.04 \pm 1.08$ & $32.18 \pm 1.35$ & $891.05 \pm 215.04$ \\
\hline $\begin{array}{l}\text { Window was opened during teaching } \\
\text { hour; 11 people in Room_1 (for 45 min) }\end{array}$ & $21.71 \pm 0.28$ & $24.65 \pm 0.53$ & $590 \pm 0.53$ \\
\hline
\end{tabular}


During this research a local application (built in C\# programming language) was developed that informed the user about current readings and the recommended values. It graphically represented the obtained data from the database, showed minimum, maximum, average values in the room per specified period. Also, comparing the latest data with the recommended values in case of inappropriate data warned the user.

By comparing our results with other researches, it could be concluded that they are similar. The author [9] states that the $\mathrm{CO}_{2}$ level at the beginning of each class (student count 15-18) increased rapidly by exceeding the recommended value (during the day even over $3000 \mathrm{ppm}$ ), but the lowest concentration (from $419 \mathrm{ppm}$ to $517 \mathrm{ppm}$ ) was registered at night or before the first class. This was observed also in our case, where the rapid $\mathrm{CO}_{2}$ level increase can be clearly seen in Fig. 2 and the lowest $\mathrm{CO}_{2}$ level in an empty Room_1 in Table 1. Also [13] states that the $\mathrm{CO}_{2}$ level exceeded $(1200 \mathrm{ppm})$ the recommended value. However, there are differences in temperature values, [9] research recorded temperatures close to $30^{\circ} \mathrm{C}$, in our case the maximum was close to $26{ }^{\circ} \mathrm{C}$, but [13] recorded values about $19^{\circ} \mathrm{C}$. Relative humidity values, by [9] experiments, were below $40 \%$ outside teaching hours and did not exceed the maximum recommended values. Also [13] recorded the relative humidity value of about $44 \%$. In our case relative humidity was mostly about the recommended minimum values.

\section{Conclusions}

Measurement data interpretation showed that the $\mathrm{CO}_{2}$ level never reached a steady state when there were students in the room. Since there are $\mathrm{CO}_{2}$ level fluctuations (due to various changes of the people count in the computer laboratory), it is only possible to get an overall insight about the $\mathrm{CO}_{2}$ levels. It was concluded that during practical assignments in Room_1, the $\mathrm{CO}_{2}$ level was always above the recommended value $(1000 \mathrm{ppm})$, the temperature was only slightly above the recommended maximum (never more than $+1{ }^{\circ} \mathrm{C}$ ), except one day; humidity measurements showed, that the air is very dry, since it reached the minimum recommended value only in two days.

The monitored microclimate parameters in Room_1 do not correspond to the recommended values during student practical assignments, when the room is not ventilated. The experiments showed that only if Room_1 was ventilated periodically by opening the window during breaks, the monitored parameter values were kept at the recommended values, e. g., the average $\mathrm{CO}_{2}$ level was 891.05 $\pm 215.04 \mathrm{ppm}$, temperature $22.04 \pm 1.08{ }^{\circ} \mathrm{C}$ and relative humidity $32.18 \pm 1.35 \%$. It is also worth mentioning that the monitored computer laboratory was never occupied with maximum student count (16 students).

\section{References}

1. Kalibatas D., Zavadskas E. K. Multiple criteria analysis of indoor climate at the workplace. Proceedings of the 9th international conference "Modern Building Materials, Structures and Techniques.", 2007, Vilnius, Lithuania, pp. 141-142.

2. Seppanen O., Fisk W. J., Faulkner D. Cost benefit analysis of the night-time ventilative cooling in office building. Lawrence Berkeley National Laboratory, 2003, 6 p.

3. Seppanen O.,Fisk W. J. A procedure to estimate the cost effectiveness of the indoor environment improvements in office work. Creating the Productive Workplace. Second edition. London: Taylor \& Francis, 2006, pp. 407-433.

4. Technical Indoor Climate Guide. 2014. 144 p. [online][09.01.2017]. Available at: http://www.swegon.com/PageFiles/106535/Indoor_climate_guide.pdf

5. Iekštelpu gaiss (Indoor air)(In Latvian). [online][09.01.2017]. Available at: http://www.vi.gov.lv/lv/vides-veseliba/gaiss/iekstelpu-gaiss/

6. Darba vides parametri (Work environment parameters) 2008. 11 p. (In Latvian). [online][ 09.01.2017]. Available at:

http://www.inspecta.com/Documents/Latvia/DA/Vadlinijas_Darba_vietas_parametri.pdf

7. Krawczyk D. A., Gładyszewska-Fiedoruk K., Rodero A. The analysis of microclimate parameters in the classrooms located in different climate zones. Applied Thermal Engineering, vol. 113, 2017, pp. 1088-1096. 
8. Darba aizsardzības prasības darba vietās (Occupational health and safety requirements for the workplace) (In Latvian).[online][09.01.2017] Available at: https://likumi.lv/doc.php?id=191430

9. Telejko M. Attempt to Improve Indoor Air Quality in Computer Laboratories. Procedia Engineering, vol. 172, 2017, pp. 1154-1160.

10. What are safe levels of $\mathrm{CO}$ and $\mathrm{CO} 2$ in rooms? [online][09.01.2017]. Available at: https://www.kane.co.uk/knowledge-centre/what-are-safe-levels-of-co-and-co2-in-rooms

11. PVO pētījuma „Skolu iekštelpu gaisa kvalitāte” apsekojuma rezultāti Latvijas skolās 2015./2016.mācību gadā (PVO research "Indoor air quality in schools" results in Latvian schools, school year 2015./2016.)(In Latvian). [online][01.03.2017]. Available at: http://www.vi.gov.lv/lv/vides-veseliba/gaiss/iekstelpu-gaiss/pvo-petijums

12. CO2 Levels \& Monitoring Explained. [online][09.01.2017]. Available at: https://www.co2monitor.com.au/

13. Cai W., Yoshino H., Zhu S. etc. Investigation of Microclimate and Air Pollution in the Classrooms of a Primary School in Wuhan. Procedia Engineering, vol. 121, 2015, pp. 415-422.

14. Asere L., Mols T., Blumberga A. Assessment of Energy Efficiency Measures on Indoor Air Quality and Microclimate in Buildings of Liepaja Municipality. Energy Procedia, vol. 95, 2016, pp. 37-42.

15. Arduino - Home. [online][01.03.2017]. Available at: http://arduino.cc/

16. Datasheet SHT7x (SHT71, SHT75) Humidity and Temperature Sensor IC, 2011. 12 p. [online][25.10.2016]. Available at: http://www.mouser.com/ds/2/682/Sensirion_Humidity_SHT7x_Datasheet_V5-469726.pdf

17. Datasheet: K-30 Sensor, 2015. 9 p. [online][25.10.2016]. Available at: http://img.ozdisan.com/ETicaret_Dosya/456729_1584920.PDF

18. Application Note AN-126: Arduino UART Interface to K-30 Sensor. 8 p. [online][25.10.2016]. Available at: http://www.co2meters.com/Documentation/AppNotes/AN126-K3x-sensor-arduinouart.pdf

19. testo 535 Instruction manual. 8 p. [online][01.03.2017]. Available at: https://www.instrumart.com/assets/testo-535-manual.pdf

20. ESP8266EX datasheet. 2015. 31 p. [online][25.10.2016]. Available at: https://cdnshop.adafruit.com/product-files/2471/0A-ESP8266__Datasheet_EN_v4.3.pdf

21. CO2 Sensor Location: Where to Mount Your CO2 IAQ Monitor. [online][25.10.2016]. Available at: http://www.co2meter.com/blogs/news/6056206-co2-sensor-location-where-to-mount-yourco2-iaq-monitor

22. Measuring Carbon Dioxide Inside Buildings - Why is it Important? 2013. 4 p. [online][01.03.2017]. Available at: http://www.energy.wsu.edu/Portals/0/Documents/Measuring_CO2_Inside_Buildings-Jan2013.pdf

23. Vēsturisko meteorologisko un hidrologísko novērojumu datu lejupielāde (Historical meteorological and hydrological observation data download). (In Latvian). [online][16.03.2017]. Available at: https://www.meteo.lv/jaunumi/hidrologija/vesturisko-meteorologisko-unhidrologisko-noverojumu-datu-lejupielade $?$ id=172\&cid=107 